\title{
Os pentecostais: entre a fé e a política
}

Etiane Caloy Bovkalovski de Souza D outoranda-Universidade Federal do Paraná/CNPq; Marionilde Dias Brepohl de M agalhães Universidade Federal do Paraná

\section{RESUM O}

Dentre os inúmeros movimentos sociais que surgiram na América Latina, desta cam-se os pentecostais. De diversas origens missionárias, caracterizam-se pela ênfase no reavivamento espiritual, na conversão individual, na atuação do Espírito Santo e pela perspectiva escatológica. Se, ao longo do século XX, mantiveram-se isolados da esfera pública, a partir da década de setenta, em diversos países,passam a interagir na política institucional. Discutir quais são as suas bases doutrinárias e suas principais representações políticas é o objetivo do presente artigo.

Palavras-chave: pentecostalismo; reavivamento religioso; comportamento político.

\section{ABStRACT}

This article intends to discuss the doctrine of Pentecostal groups and their main political representations. They come from several missionary origins and can be characterized by the emphasis on spiritual revival, on individual conversion, on the presence of the Holly Ghost and by the belief on eschatology. For a long time during the twentieth century, they were distant from politics. But, beginning in the 70 's, in many countries of Latin America,they decided to belong to political parties or political groups. Keywords: Pentecostal groups; religious revival; political behavior. 
(...) Então, os apóstolos Ihes impunham as mãos e recebiam estes o Espírito Santo. Vendo, porém, Simão que, pelo fato de imporem os apóstolos as mãos, era concedido o Espírito Santo, ofereceu-Ihes dinheiro, propondo: Concedei-me a mim este poder. (...) Pedro, porém, replicou: Pereça teu dinheiro e tu com ele (...)

Atos dos A póstolos 8:17-18

0 crescimento dos movimentos religiosos de inspiração pentecostal na América Latina, subcontinente tradicionalmente católico, éum dos fenômenos culturais mais surpreen dentes da atualidade. De um contingente que se apresentava como uma subcultura avessa à exposição pública eauto-enclausurada, hoje sua presen ça se destaca não apenas no que diz respeito ao contingente numérico, mas principalmente por sua visibilidade nos meios de comunicação de massa.

Surpreendente também é sua recente interferência na esfera pública, 0 que tem atraído a atenção de pesquisadores, políticos ejornalistas. Esta nova ten dência contrasta com o comportamento anterior, que foi assim caracterizado por René Padilla:

La influencia de misioneros cuya enseñanza ( tal vez más por lo que eran que por lo que decían) pasaba completamente por al to la responsabilidad social y política de los cristianos.

El complejo de minoría de los evangél icos,fraguado en un ambiente de hostilidad (y hasta de abierta persecución religiosa), un ambiente donde la cuestión de su propia sobrevivencia necessariamente ha desplazado todas las preguntas que podrían haberse hecho sobre su posible aporte a la construcción de una nue va sociedad.

El énfasis en una escatolología futurista en las igl esias evangélicas, a la luz de la cual la misión de la iglesia se reduce a la salvación de las al mas, en tanto que la acción social y política queda regalada al ámbito de tareas ajenas al interés de los cristianos. ${ }^{1}$

Desta feita, se até a década de sessenta, sua atuação na política era extremamente tímida, limitando-se a demandas de caráter corporativo (como instituição do dia da Bíblia,dia da Reforma,inauguração de praças públicas com nomes evocativos de seus fundadores, pedido de verbas para a construção de templos), na atualidade, organizam-se para lançar e eleger seus próprios candidatos.

Nos últimos anos, segundo Padilla, ainda que a ênfase na iniciativa indi- 
vidual persista, ela tem cedido espaço para uma atuação política cada vez mais distinguida. Citem-se, como exemplos, a criação de um partido político próprio na Venezuela, em 1978 (O rganización Renovadora Auténtica); o surgimento da "Bancada Evangélica", com trinta e três deputados na Assembléia Constituinte no Brasil (1986); sua interferência na eleição do primeiro mandato de Alberto Fujimori, no Peru, em 1990; a eleição de Jorge Serrano Dias, membro da I greja Pentecostal El Shaddai (Deus Onipotente), como presidente da Guatemala; a criação de um partido político "evangélico" na Argentina em 1991; e, em todos os países, destaque-se também a criação de um sem número de organizações não-governamentais de combate às drogas, ao al coolismo e de atendimento ao menor carente, bem como a intervenção no mercado de votos.

Antes de discorrermos sobre sua presença e atuação na esfera política, consideramos interessante expor al gumas das motivações que levam à conversão de tão grandenúmeros de indivíduos ao pentecostalismo, bem como tecer al guns comentários sobre sua identidade religiosa.

\section{A IDENTIDADE PENTECOSTAL}

0 crescimento das confissões pentecostais na América Latina é explicado por M ariano, devido à forma mesma como este movimento se expandiu no continente. Segundo o autor, ela pode ser identificada a partir de três ondas $^{3}$ que, embora distintas, não são excludentes entre si:

A chamada Primeira Onda ou Pentecostalismo Clássico, que corresponde ao período situado entre 1910 e 1950. No Brasil, a primeira organização foi fundada por missionários italianos de origem valdense, a Congregação Cristã no Brasil (1910, em São Paulo); imediatamente após, funda-se, em 1911, a Assembléia de Deus, no Pará, por missionários suecos, que se expande em todo o território nacional. No Chile, al guns metodistas iniciam a prática missionária, mas, devido a divergências com esta denominação, sectarizam-se e organizam um movimento próprio, elevando o percentual de crentes de 1,1\% (1907) para 20\% (1970)4. Caracteriza-se desde o começo por forte oposição ao catolicismo, pela ênfase na glossolalia ( falar em línguas ${ }^{5}$ ), ênfase na evangelização dos povos indígenas e conduta ascética ou de rejeição ao mundo.

A Segunda Onda ou Pentecostalismo N eoclássico, que associou o dom de falar em línguas como sinal do batismo do Espírito Santo, à "cura divina". É neste período também que os missionários vão se emancipando das organizações estrangeiras e criando suas próprias organizações, donde a segmentação. No Brasil,este movimento se inicia com a chegada de dois missionários 
norte-americanos, Harold Williams e Raymond Botright, pertencentes à I greja Internacional do Evangelho Quadrangular (International Church of The FoursquareGospel). Criam a Cruzada Nacional de Evangelização baseados na cura divina elogo fundam em São Paulo, no ano de 1951, a I greja do EvangeIho Quadrangular (IEQ) que, à diferença das demais, é predominantemente liderada por mulheres. Ainda, a Igreja Brasil Para Cristo (1955, São Paulo), Deus É Amor (1962, São Paulo), Casa da Benção (1964, Minas Gerais), e outras de menor porte.Em El Salvador, a Assembléia de Deus e a I greja de Deus, fundadas por missionários norte-americanos, elevaram o percentual de evangélicos,neste mesmo período, de $3 \%$ para $18 \%{ }^{6}$. No Peru,é também a Assembléia de Deus quem se responsabiliza, a partir de 1940, pelo crescimento da presença pentecostal (na cidade de Lima, atinge o percentual de $12 \%$ em 1987) ${ }^{7}$. Duas características são marcantes neste período: o uso do rádio para difusão do Evangelho e as tendas delona, que aproximam os pregadores do público.

Finalmente, a chamada Terceira O nda ou N eopentecostal, que começa na segunda metade da década de 70 e ainda se encontra em processo de crescimento. Fenômeno comum a todo o continente, seus líderes são, na maioria, pregadores nacionais. Com o uso intenso da mídia el etrônica (que também é denominada de tel evangelismo), este período se caracteriza pela consolidação do pentecostalismo como força social e política.

Segundo Freston, em uma estimativa conservadora realizada entre 199094, calcula-se que 45 milhões de latino-americanos sejam evangélicos, dos quais, 1/3 protestantes ${ }^{8}$ e 2/3 pentecostais. A pentecostalização do universo evangélico de cada país varia de $30 \%$ nos Andes (onde 2 a $5 \%$ da população é evangélica) a $80 \%$ no Chile (com 15 a 20\% da população evangélica). No Brasil, onde 15 a $20 \%$ da população é evangélica, $62 \%$ é pentecostal. Na Guatemala, dentre os $30 \%$ de evangélicos, $75 \%$ é pentecostal ${ }^{9}$.

Stoll confirma esta tendência: segundo ele, de 1960 a 1985, o número de evangélicos duplicou no Chile, Venezuela, Paraguai, Panamá e Haiti. Na Argentina, Nicarágua e República D ominicana, triplicou. No Brasil e em Porto Rico, quadriplicou. Em El Salvador, Costa Rica, Peru e Bolívia, quintuplicou. No Equador, Colômbia e Honduras,sextuplicou. E na Guatemala,cresceu sete vezes ${ }^{10}$. Já um alarmista da I greja Católica, porta-voz do Vaticano, afirmou que tais seitas teriam crescido $500 \%$ nas últimas décadas, devido à televangelização ${ }^{11}$.

Além do aumento de adeptos, cite-se a pluralidade de organizações.Várias são as denominações surgidas nos anos setenta e oitenta, das quais a mais conhecida, quer pelo seu tom estridente, quer pelo seu intenso proselitismo em todos os países da América Latina, éa I greja Universal do Reino de Deus 
(fundada em 1977, pelo bispo Edir M acedo), a qual será analisada com maior profundidade a seguir. Seguem-se-Ihe a Assembléia de D eus e a Congregação Cristã, com diversos nomes, que variam de país para país.

O uso dos meios de comunicação de massa são um contributo de inegável importância e, por certo, as estratégias adotadas provêm dos Estados U nidos, tendo como modelo principal a figura do pregador norte-americano Billy Graham.

0 méto do deste pregador, que se projeta nos Estados Unidos desde o final da Segunda Guerra Mundial até a el ei ção de Nixon, pode ser assim sintetizado: reunir multidões sob uma cobertura desmontável e realizar pregações ao ar livre, nas quais a ênfase na culpa pelo pecado e a necessidade de arre pendimento para a salvação eram o tema principal, enfatizando-se ainda que, mesmo aqueles que já er am convertidos, deveriam despertar-se para a sua fé ( revival), não apenas com palavras,mas com suas emoções ${ }^{12}$. Integra seus discursos a ênfase na missão redentora dos Estados U nidos, tendo como antagonista, segundo impunha o espírito da época, a União Soviética, considerada o principal inimigo da fé.

Graham corporificou o modelo a ser seguido por diversos movimentos desta natureza: o uso intenso da mídia, o anticomunismo e o tom carismático na pregação; no entanto, a linguagem e os ritos praticados na América Latina eram autóctones, elaborados por líderes nacionais, os quais, geralmente, provinham da mesma classe social de seus fiéis, vale dizer, na imensa maioria dos casos,a população pobre.N ão se tratava de mero transplante de uma cultura, mas de sua adaptação a uma demanda religi osa já em processo de crescimento.

O fato de terem tais tendências encontrado eco, principalmente,mas não só, entre as classes pobres, leva Galindo a afirmar que:

Sociologicamente se fala de pentecostalismo como da "religião dos pobres". Com isso alude-se não só às pessoas que o iniciaram mas também ao fato de que entre os pobres a fé cristã costuma ser enten dida e vivida de maneira diferente da das classes acomodadas. Os pobres não possuem livros, emesmo que os tivessem não disporiam de tempo e de preparação para estudá-los. Isso leva a uma religião que dá pouca importância ao fator intelectual e muita ao emocional,aos sentimentos. Os conceitos só são aceitos quando confirmados, convalidados e legitimados pelos valores da própria cultura (...)

O pentecostalismo globalmente representa esse tipo de cristianismo desinteressado da doutrina e centrado no emocional, na vivência do sobrenatural. Por isso são tão importantes, nele, os milagres, os sinais como o falar em línguas (glossolalia), as curas, os exorcismos ${ }^{13}$. 
Se tais considerações estão corretas, em um continente em que a pobreza não cessa de crescer, as razões para o crescimento de tais movimentos eorganizações religiosas parecem ser evidentes. M as seria só o empobrecimento cada vez maior do continente o elemento chave para entendermos o crescimento da denominação pentecostal? Ainda,somente os pobres afastam-se de elaborações intelectuais em favor da percepção do mundo a partir das emoções?

Essas inquietações nos conduzem a M ax Weber, para quem a rotinização do carisma e a apropriação dos poderes que dela decorre, pode se constituir em fator explicativo para tal crescimento ${ }^{14}$.

Para o caso de que estamos tratando, cite-se, como evidência desta distribuição de poderes, o número de pastores na I greja Universal do Reino de Deus - IURD: Segundo Campos, em 1995, contavam-se, aproximadamente, com 1 pastor para cada 428 fiéi $s^{15}$. Ressalte-se ainda que as casas de culto são muito simples,situadas em todos os pontos das cidades, e os pastores provêm do mesmo grupo social dos fiéis (prescindindo-se, portanto, do alto custo pa ra a edificação de templos tradicionais e do custo para a formação teológica), o que também se aplica para a Assembléia de D eus e a I greja do Evangelho Quadrangular.

Outros fatores de atração específicos do pentecostal ismo podem ser mencionados. Sobre eles, a bibliografia especializada no tema se caracteriza por duas tendências principais.

A primeira, da qual fazem parteautores como Galindo, M ariano, Peter Fry ${ }^{16}$ e outros, defende que o fenômeno pentecostal é conseqüência direta da pobreza e desespero das classes pobres. 0 apelo emocional dos seus líderes, os cantos estridentes,a violência nos atos de exorcismo, a exploração dos fiéis na cobrança do dízimo são evidências da manipulação realizada por pessoas pouco escrupulosas em face de um povo ignorante. N ão raramente, associase tal crescimento aos interesses do imperialismo norte-americano, num "plano de penetração ideológica" daqueles para, como se fosse um complô, exercer dominação sobre o continente.

Estas tendências interpretativas são, a nosso ver, altamente questionáveis; primeiro, por não levarem em conta dados empíricos que colocam em evidência a autoctonia da maioria das denominações pentecostais; segundo, por não responderem à seguinte pergunta: se a motivação básica é o desespero ante a miséria, por que a fidelidade a denominações que inclusive lhes cobram o dízimo? Por que as classes médias e mesmo ricas adeririam ao movimento? Terceiro: subjaz a tais críticas o preconceito iluminista de que somente o discurso racional pode autorizar os movimentos sociais; os demais são, no limite, manifestações anômicas. Ainda, há de se considerar que tais interpretações procedem de profissionais que são quase sempre de esquerda, o que os 
leva a hostilizar quaisquer manifestações religiosas como "ópio do povo", exceto a Teologia da Libertação, que parece ser a grande perdedora no mercado religioso em face do crescimento do pentecostalismo. Finalmente, porque estas pesquisas são influenciadas pela contra-ofensiva da I greja Católica, em boa medida auxiliada pelos meios de comunicação de massa, que enxergam no televangelismo um ameaçador concorrente ${ }^{17}$.

Afastamo-nos de tais interpretações ainda por uma outra razão: em que pese reconhecermos o autoritarismo exercido por muitos desses líderes religiosos, a exploração econômica a que submetem seus fiéis, o assédio por parte de diversos políticos a estes fiés durante suas campanhas eleitorais, o fisiologismo político dos mesmos, entre outros aspectos (práticas que, de resto, encontram-se presentes em outras organizações religiosas e não-religiosas da América Latina), estas análises não resultam de um estudo que leve em conta a dimensão do sagrado enquanto experiência constitutiva de determinadas sociedades ou culturas.Entendem a religião como um discurso externo a seus próprios interlocutores,ou ainda, como zona periférica da existência humana.

No entanto, como bem nos esclarece $M$ enshing, a religião éa experiência humana do encontro com o sagrado e de ação do homem em consonância com 0 impacto produzido por esse encontro ${ }^{18}$. Assim sendo, a religião está profundamente associada a uma determinada experiência que escapa ao cotidiano, ao pal pável: a uma realidade essencialmente ambivalente: do mysterium tremendum (estranho, medo), e do mysterium fascinans ( o aprisionamento que gratifica), experiência presente em quaisquer experiências com o sagrado, em todas as épocas e sociedades. Considerá-las como fruto de mera manipulação ideológica é subtrair às camadas populares sua capacidade de discernimento, tanto quanto reti rar-Ihes o caráter de atores intervenientes em sua própria cultura.

Uma outra premissa que também recusamos, e que foi até bem pouco hegemônica nas Ciências Sociais: de que qualquer religião leva necessariamente à submissão e ao conformismo. Não foi assim, no período que antece deu a Revolução Inglesa, nas insurrei ções dos anabatistas à época de Lutero, com os adeptos da Teologia da Libertação na América Latina e mesmo entre os pentecostais, de quem nos ocupamos agora.

Estas convicções nos conduzem,não sem al gumas reservas que serão aqui explicitadas, à segunda corrente interpretativa, que procura entender o crescimento do pentecostalismo na América Latina,i dentificando nele manifestações de uma cul tura religiosa autóctone e representativa das camadas populares. Procuram analisá-lo a partir de sua historicidade, afirmando ainda que sua presença coopera para a democratização dos poderes religiosos.

N ossas ressalvas com relação a esta segunda corrente incidem sobre dois 
aspectos: $10-0$ antiintectual ismo quase militante destes movimentos, tradição oriunda dos movimentos congêneres norte-americanos. Dificilmente se encontra no seio dos movimentos pentecostais brasileiros entidades interessadas em formar quadros capacitados a dialogar com as instituições seculares, ou mesmo com os seus próprios membros. Desta maneira, ainda que sua liderança seja nacional, a au toctonia postulada não se confirma integralmente, porquanto muitos deles permanecem firmemente leais à cultura de origem; $2 \underline{0}-$ ao mencionarem a democratização dos poderes religiosos em face da hegemonia da I greja Católica, o que efetivamente ocorre, não atentam todavia para o autoritarismo interno praticado em tais organizações, em que a figura do líder é venerada e obedecida sem quaisquer mediações ${ }^{19}$.

Ainda assim, estes estudos, que vêm de se desenvolver com maior intensidade nos dias atuais, permitem-nos uma compreensão mais clara a respeito dos fatores que têm atraído os indivíduos ao pentecostalismo.

René Padilla observa que as denominações pentecostais florescem numa configuração do mundo religioso, onde o "magisterium" catolicoromano representa ... un sistema de opresi ón que impone normas y conductas sobre las grandes mayorías ${ }^{20}$, a partir de estruturas rigidamente hierarquizadas, o que levaria a que as populações subalternas Ihes fizessem resistência, formando igrejas livres de caráter menos institucional e mais pessoal.

Para o autor, esta éinclusive uma tendência de longa duração; nos últimos cinco séculos, a tradição reformada sempre foi um ato subversivo, porquanto contestou a hegemonia da I greja Católica que mantinha íntimas relações com o poder temporal.

David Martin vai mais além: compara o pentecostalismo latino-americano com o metodismo inglês do século XVIII ${ }^{21}$. Segundo ele, o metodismo floresceu como reação à I greja Anglicana, que representava os poderes constituídos. Graças a ele, consolidou-se a separação entre I greja e Estado e observou-se um franco avivamento da fé, pela solidariedade, estudo da Bíblia e atendimento das aspi rações cotidianas de seus seguidores. Estavam ali plantadas as sementes de uma nova experiência política, ainda que não intencional, qual fosse a demanda pela ampliação dos direitos civis. Este desdobramento parece confirmado pelo historiador E.P. Thompson, quando analisa a estrutura do metodismo inglês e a formação da classe operária inglesa ${ }^{22}$.

Uma evolução semelhante pode ser encontrada,segundo Martin,nas seitas "evangélicas" atuais.Enquanto a I greja oficial pressupõe a integração de todos os fiéis num sistema socioreligioso hegemônico, as denominações evangélicas fomentam o compromisso pessoal eo sacerdócio de todos os crentes, o que, conforme nosso entendimento, el eva a auto-estima e atribui significado à vida de muitos destes indivíduos. 
Paul Freston nos permite um aprofundamento ainda maior na compreensão sobre o crescimento do pentecostalismo. Recusa com maior ênfase a tese de que tal fenômeno se deva exclusivamente ao agravamento da miséria; para ele,este fator podeser relevante, mas não é primordial. Advoga para tanto que aspectos culturais, sociais e religiosos (ou seja, as dimensões do sagrado) sejam considerados tão importantes quanto os aspectos políticos e econômicos.

Segundo ele,

A religião é ambivalente e oferece diferentes coisas a diferentes indivíduos. (...) 0 pentecostalismo é flexível e éimprovável haver uma única razão para o seu crescimento (...) é necessário levar-se em conta não apenas os fatores econômicos e políticos, mas sociais, culturais, étnicos e religiosos; não apenas o nível macro (quais são as configurações favoráveis à conversão) mas também o nível micro (porque as pessoas com estas características se convertem) ${ }^{23}$.

Dentre elas,mencionese a experiência com o Espírito Santo, que é passível de ser vivenciada por todos os membros. O Espírito Santo representa aí uma força sobrenatural,inspirando a palavra de poder (e não o poder da palavra), estimulando a coragem e a experiência extática, tanto quanto as profecias e curas milagrosas ${ }^{24}$. A ênfase na "revelação do Espírito Santo" éimportante ainda por estimular a participação dos iletrados ${ }^{25}$.

Diferentemente de outras confissões,o pentecostalismo se segmenta, pois subjaz a ele uma estrutura flexível. Segundo Freston, por não depender de um clero formal, pode se organizar em qualquer localidade, por menos expressiva que seja política ou numericamente. Assim se caracteriza também sua liderança; não depende de formação teológica, mas emerge da própria comunidade - o que permite alto nível de adaptação às culturas locais, diferentemente do protestantismo histórico, que manteve, em maior ou menor grau, fidelidade às suas tradições européias. Um dos exemplos mais ilustrativos desta tendência é o da I greja Luterana, tanto no Chile, como na Argentina, Uruguai eBrasil, ondea cultura germânica foi reforçada pela confissão religiosa, dificultando ou mesmo impedindo a filiação de outros grupos sociais, bem como a integração daqueles imigrantes à sociedade receptor $2^{26}$.

Com respeito à conexão entre carência econômica e religião, Freston afirma não estar esta associada a um discurso de cima para baixo, mas sim ao fato de que todo indivíduo religioso busca soluções em sua fé. N uma feliz leitura sobre religi osidade e aspiração à prosperidade econômica,afirma que o pentecostal ismo reforça a ética do trabalho, auxiliando inclusive os desempregados a montar seu próprio negócio, ainda que seja na economia informal. Ao lado do rigor ascético (como a sublimação sexual, o interdito ao fumo, às dro- 
gas e ao alcoolismo) e da ajuda mútua (irmão ajuda irmão), os pentecostais logram estratégias de sobrevivência querecolocam as noções puritanas deprosperidade, mas não subordinadas, como há dois séculos, à salvação²7.

É justamente sobre este aspecto - a ênfase na prosperidade econômica - que gostaríamos de concentrar, a seguir, nossa atenção, uma vez que a partir deste tema podemos identificar as conexões entre as sensibilidades religiosas deste grupo, sua doutrina e sua posição em face da política.

\section{A TEOLOGIA dA PROSPERIDAdE: UMA RESPOSTA À TEOLOGIA DA LIBERTAÇÃo?}

Com o intuito de entender como a aspiração por bens materiais se relaciona com a cosmovisão política dos neopentecostais, tentaremos num primeiro momento esclarecer, ainda que de forma muito breve, o desenvolvimento da Teologia da Prosperidade e, num segundo momento, ilustrar, a partir do exemplo da I greja Universal do Reino de Deus - IURD, uma das denominações de mais rápido crescimento na América Latina nas duas últimas dé cadas, como esta doutrina foi apropriada e difundida neste subcontinente, para então discorrermos sobre sua participação na política.

\section{A base doutrinária}

A Teologia da Prosperidade pode ser considerada como um desdobramento do fundamentalismo norte-americano, o qual, após a crise de 29, reorienta sua ética em favor de uma maior participação na esfera pública, devido, em boa medida, ao aumento de seus contingentes e, por via de conseqüência, de seu peso eleitoral; para orientar suas práticas, sob a égide da Guerra Fria, desenvolvem inicialmente a doutrina do M ilenarismo, calcada na perspectiva escatológica. Foi desenvolvida de duas maneiras: a primeira, compreendida como pós-milenarista, consiste na crença de que se os fiéis adotarem uma ética solidária durante mil anos, Jesus voltará para julgá-los e premiá-los. Daí sua ênfase na ajuda mútua, na devoção, na filantropia. D esta convicção compartilham os assim chamados Evangelicals, como Billy Graham e Jimmy Carter. Esta compreensão foi pouco a pouco sendo considerada utópica, donde uma segunda corrente interpretativa, a do pré-milenarismo. N esta versão, não cabe aos crentes tentar melhorar a situação do mundo, pois a decadência faz parte dos planos de Deus. A ruína precede a segunda vinda de Cristo, que virá para conduzir os el ei tos até os céus, e depois retornará para com eles dominar a Terra, para julgar os descrentes e premiar os fiéis. I sto explica sua recusa às políticas sociais ou a qualquer sorte de filantropia, pois os males sociais 
são vistos como castigo divino aos infiéis; portanto, a pobreza dos hispânicos e dos negros (cujo atendimento era financiado pelos "laboriosos brancos") só seria superada pela sua conversão (born again). É neste contexto que se organiza a M aioria M oral, cujo objetivo era influenciar a política tendo em vista a recristianização da América ${ }^{28}$. Esta influência é perseguida através da evangelização em massa, com uso intenso dos meios de comunicação.

É desta corrente que surge uma outra variante,segundo nossa compreensão, mais radical ainda, qual seja, a Teologia do D omínio, que pretende transformar o mundo através de suas elites dirigentes. Para tanto, deve-se conquistar o poder através das suas instituições oficiais, mas, fundamentalmente, formar as elites de amanhã. É por isto que, além de investirem na Igreja Eletrônica, criam universidades e escolas para educar os "seus" jovens. A Liberty University éo exemplo paradigmático desta tendência: ministra-seali um ensino rigorosamente científico, com disciplinas e conteúdos seculares. São jovens que, em regime de internato, preparam-se para, quando profissionais, resistirem à sedução da modernidade, o que lhes garantirá uma vitória cultural nos Estados Unidos e depois, em todo o planeta.

Segundo Stoll, a convicção de ter a elite norte-americana um papel especial no plano de Deus ${ }^{29}$, levou a que muitos crentes aderissem, de forma ainda mais entusiástica, à pregação da doutrina em todo o mundo, mensagem acompanhada por um anticomunismo virulento, visto como representante de Satanás na Terra. Contra ele, a principal virtude do capitalismo deveria ser difundida, ou seja, a prosperidade e o espírito de iniciativa. Dentre as três, é esta última a mais difundida na América Latina, e quiçá, em todos os demais continentes.

A Teologia da Prosperidade ou Confissão Positiva teve sua origem na dé cada de 40 nos Estados Unidos, sendo reconhecida como doutrina na década de 70, quando se difundiu pelo meio evangélico. Possuía um for te cunho de auto-ajuda e valorização do indivíduo, agregando crenças sobre cura, prosperidade e poder da fé através da confissão da "Palavra" em voz alta e "N o Nome de Jesus" para recebimento das bênçãos almejadas; por meio da Confissão Positiva,o cristão compreende que tem direito a tudo de bom e de melhor que a vida pode oferecer: saúde perfeita, riqueza material, poder para subjugar Satanás, uma vida plena de felicidade e sem problemas. Em contrapartida, dele é esperado que não duvide minimamente do recebimento da bênção, pois isto acarretaria em sua perda, bem como o triunfo do Diabo ${ }^{30}$. A relação entre o fiel e Deus ocorre pela reciprocidade, o cristão semeando através de dízimos e ofertas e Deus cumprindo suas promessas. 


\section{UMA TEOLOGIA DE RICOS PARA OS POBRES: O CASO DA IURD}

Esta estrutura de pensamento pode ser encontrada nos livros do bispo Edir Macedo, fundador e principal líder da IURD, nas décadas de 80,90 e ano de $2001^{31}$.

N esta denominação, os pastores afirmam que só não é abastado quem não quer: as bênçãos estão ao alcance de todos mediante a fé, inclusive com a al teração radical de realidades miseráveis em vidas prósperas; porém, se alguém tiver qualquer envolvimento direto ou indireto com o Diabo ou não estiver disposto a "sacrificar" para a obra de D eus, não será agraciado. Este mecanismo permite explicar porque muitos fiéis não alcançam a graça.

Segundo Gomes, o termo "graça" pode ser traduzido pela posse de bens em vista de sua fruição $0^{32}$, sinal da natureza bondosa de Deus. Contra a Sua vontade, antepõe-se um elemento perturbador, o Diabo, o qual, embora inferior em seu poder, interfere nesta relação, para confundir os fiéis e impedi-los de usufruir dos bens. Não é portanto primordialmente o pecado (individual ou social) que impede a posse dos bens, mas o Diabo, que age segundo seu próprio arbítrio, contra quem o crente deve lutar. Uma vez que a responsabilidade fica por conta do fiel e do Diabo, cria-se uma linha de tensão entre a posse da bênção ea atuação diabólica.

Por estas razões de ordem doutrinária, a dinâmica Benção - Diabo Posse, e, em outro extremo, a vontade de Deus, é que a Teologia da Prosperidade corrobora com o anseio de acomodação ao mundo de certas lideranças, com a possibilidade de mobilidade social para al guns fiéis e com a manutenção de um statusjá adquirido para outros,sem o sentimento de culpa.Em vez de ouvir num sermão que "é mais fácil um camelo atravessar um buraco de agulha do que um rico entrar no Reino dos Céus" (Mateus 19,24 e M arcos $10,25)$, agora a novidade reside na possibilidade de desfrutar de bens e riquezas, sem constrangimento e com a aquiescência de Deus.

Para os afortunados, esta abordagem traz alívio; para os pobres, o direito de possuir como filho de Deus. Segundo Edir M acedo, Jesus veio pregar aos pobres para que estes se tornassem ricos. Arrependimento e redenção, tema central no Cristianismo, e as dificuldades nesta vida para o justo de Deus são temas raramente tratados. Por isso, na busca da bênção, o fiel deve determinar, decretar, reivindicar e exigir de Deus que Ele cumpra sua parte no acordo; ao fiel compete dar dízimos e ofertas. A Deus cabe abençoar ${ }^{33}$.

Macedo ensina como proceder:

Comece hoj e,agora mesmo, a cobrar d'Ele tudo aquilo que Ele tem prometido (...) 0 ditado popular de que 'promessa é divida' se aplica também para Deus. 
Tudo aquilo que Ele promete na sua palavra é uma dívida que tem para com você (...) Dar dízimos é candidatar-se a receber bênçãos sem medida, de acordo com o que diz a Bíblia (...) Quando pagamos o dízimo a Deus, Ele fica na obrigação (porque prometeu) de cumprir a Sua Palavra, repreendendo os espíritos devoradores (...) Q uem é que tem o direito de provar a Deus, de cobrar d'Ele aquilo que prometeu? 0 dizimista! (...) Conhecemos muitos homens famosos que provaram a Deus no respeito ao dízimo e se transformaram em grandes milionários, como o sr. Colgate, o sr. Ford e o sr. Caterpilar. (M ACED O, Vida com Abundância, p. 36)

\section{E prossegue:}

Ele(Jesus) desfez as barreiras que havia entre vocêe D eus eagora diz - volte para casa, para o jardim da Abundância para o qual você foi criado e viva a Vida Abundante que Deus amorosamente deseja para você (...). Deus deseja ser nosso sócio (...). As bases da nossa sociedade com D eus são as seguintes: o que nos pertence (nossa vida, nossa força, nosso dinheiro) passa a pertencer a D eus; e o que é d'Ele (as bênçãos, a paz, a felicidade, a alegria, e tudo de bom) passa a nos pertencer. (M ACEDO, Vida com Abundância, pp. 25,85-86)

Ao estabelecer esta relação de reciprocidade com Deus, o que ocorre é que Ele, Deus, fica na obrigação de cumprir todas as promessas contidas na Bíblia na vida do fiel. Torna-se cativo de sua própria Palavra.

Devido a essa abordagem, a Teologia da Prosperidade é alvo de muitas críticas entre os pastores evangélicos, que alegam ser tal mensagem dirigida propositadamente a um contingente pobre que busca alívio para suas aflições. Ainda, que esta doutrina busca confrontar Deus e diminuir sua soberania, pois é o fiel quem define qual seja a vontade de Deus e não o contrário.

Nas palavras do pastor batista I saltino Coelho:

Há poucos meses, ocorreu em Brasília um congresso que mostrava os princípios para enriquecer. U m dos temas foi “Como se apossar das riquezas dos incrédulos"(...). A teologia da prosperidade quer tirar a cruz do crente (...). N ão se trata de masoquismo espiritual. Isto é uma lei da vida. No mundo há sofrimentos (...). A teologia da prosperidade é alienante,parcial, injusta,setorial e elitista. A idéia de que riquezas pesso ais são resultado de nossa espiritual idade agrada muito a quem tem bens. (I saltino Gomes Coelho, pastor batista, Raio de Luz n. 91,1993)

Ao entender a Teologia da Prosperidade como injusta,cremos que o pastor citado está considerando os muitos pobres, que durante longo tempo de 
suas vidas buscarão compreender porque as bênçãos exigidas de D eus não ocorreram. Eles terão delidar com a angústia por terem falhado ou permitido que o Diabo roubasse sua graça. Ou seguir os consel hos de Edir M acedo: $N$ ós ensinamos as pessoas a cobrar de D eus aquilo que está escrito. Se Ele não responder, a pessoa tem de exigir, bater o pé, dizer 'tô aqui, tô precisando'. (M ACED O, Folha deS. Paulo, 20/6/1991).

0 tema da prosperidade faz-se bastante presente também nos cultos da IURD e programas deTV. U ma das técnicas utilizadas pela I greja é a da repetição das men sagens nas pregações: normalmente, versam sobre prosperidade financeira versus ação diabólica.Ação que passou a ser denominada ao longo do ano de 2001 de encosto: termo bastantegenérico para classificar diversos males espirituais e que também possui conotações pejor ativas para as religiões afro-brasileiras. Isto podeser entendido como uma mudança deestratégi a na abo rdagem acerca das artimanhas satânicas: o universo religioso a ser atacado continua sendo o mesmo, porém, sem agredir frontalmente aque les que participam de cultos espíritas, de umbanda ou candomblé. Numa programação diária, a Rede Record exibe o programa "Ponto de Luz - Sessão Espiritual de D escarrego", em queo pastor e apresentador exorta os que assistem sobre os perigos de acabar se tornando vítima de um encosto, sujeição muito comum, e ter a vida comprometida por estes espíritos. A ênfase recai sobre uma vida anterior e sem prosperidade financeira, e a experiência atual, após tornar-se membro da Universal, em que o entrevistado declara ter havido melhora em seu padrão de consumo. Subjaz no discurso um deslocamento que relega os fatores sociais como conseqüências históricas, em favor da disputa, por Satanás, do Reino de D eus. Os problemas sociais são bastante enfocados, porém, sem assumir ares de mudan ças conquistadas pelos próprios homens, porque as "desgraças" ocorridas no dia a dia ou até mesmo os valores sociais dominantes são fruto de uma atuação maléfica. Para explicar e enfrentar tal atuação, estão os homens escol hidos por Deus. Segundo Kepel, são homens com capacidade de inscrever os fatos aconteci dos no mundo numa sucessão de causalidades obedientes a um plano de Deus do qual el es seriam os intérpretes por excelência $(. . .)^{34}$.

No discurso da IURD e em suas mensagens, autorizadas pelos fiéis porque reconhecidas pelos mesmos como provenientes de Deus, é visível esta tendência de mergulhar-se em um mundo somente espiritual ista que reforça a figura do Diabo no inconsciente da coletividade; coletividade esta que luta todo o tempo contra o que não vê, mas que está à sua volta: o Diabo; e purifica-se através do exorcismo: uma expulsão pública do Mal que habitava o corpo do fiel.

A este propósito devemos lembrar, mais uma vez, que segundo a doutri- 
na da IURD, o indivíduo não é exatamente a sede do pecado, o que exigiria dele 0 arrependimento, mas uma vítima da ação maligna: 0 ato de pecar não deriva de sua escolha, mas o $\mathrm{M}$ al é fruto do encosto que atrapalha a sua vida, em especial a financeira, sinal de bênção.

Essas práticas remontam a uma tradição de demonologia da época medieval, contudo, a perseguição empreendida contra Satanás se dá, hoje, numa expulsão pública e violenta que expõe o possesso como a vítima canalizadora do $\mathrm{M}$ al, e não necessariamente um indivíduo que fez um pacto com o Diabo. N um mundo que agoniza mediante as constantes lutas entre o Bem eo Mal, to dos somos vítimas em poten cial,sem responsabilidade pelos nossos atos, uma vez que vivemos à mercê de um conflito espiritual. Segundo Macedo, 0 mero contato ou aproximação com espíritas, por exemplo, podeacarretar em possessão demoníaca. Novamente é enfatizada a figura do Diabo, cuidadosamente construída através da Pedagogia do $\mathrm{M}$ edo $^{35}$.

M edo, porque a satanização dos acontecimentos desenvolve estruturas emocionais no fiel que em tudo vênão a mão de Deus, ou a responsabilidade de seus atos sobre o curso da sua história, mas do Diabo, que acaba por tornar-se um referencial de comportamentos socioculturais. Para a cura das doenças, solução para o casamento, prosperidade financeira e tantos outros problemas é necessário o exorcismo, que trará o milagre e a libertação. 0 próprio Macedo admite que, pel o menos na hora em que ocorre o exorcismo, a pessoa fica curada. Ser curado ou adquirir livramento pela expulsão de Satanás é um ritual necessário, pois, conforme M acedo, amera recusa em aceitar a atuação de um demônio pessoal é um indício de possessão.

Desta feita, Deus, na IU RD, é um instrumento nas mãos do fiel. I ronicamente, Ele, Deus, deve ser obediente e cumprir todas as exigências feitas pelo fiel, principalmente daquele que paga o dízimo: Tudo que fazemos, seja correntes ou campanhas,é com espírito de luta, exigindo de Deus(grifo nosso) aquilo que Ele nos prometeu. (M ACEDO, Mensagens, p. 22)

A relação que se estabelece agrega um forte simbolismo ao dinheiro: 0 fiel propõe trocas com D eus para conseguir a bênção desejada. Cabe ao fiel demonstrar revolta diante de D eus e "de dedo em riste" exigir que as promessas bíblicas se cumpram. A Terceira O nda ou N eopentecostalismo se caracteriza exatamente por este tipo de relacionamento do fiel com Deus,inspirada na Teologia da Prosperidade:o cristão tem direito a tudo de bom e de melhor neste mundo. N as palavras de Macedo: A Bíblia tem mais de 640 vezes escrita a palavra oferta. O ferta é uma expressão de fé. Se Deus não honrar o que falou há três ou quatro mil anos, eu é que vou ficar mal. (MACEDO, O Globo, 29/4/1990).

Neste discurso, a soberania de D eus é compartilhada pelo fiel na relação 
de troca. É incentivado que o fiel seacomodeao mundo das novas tecnologias, acumule riquezas, more melhor, possua carro e não tenha sentimento de culpa por não negar o mundo; pelo contrário, a conduta ascética tem diminuído entre os pentecostais desde a década de 70.

Na relação de troca o fiel dá o dízimo, ofertas, participa das campanhas: É necessário dar o que não se pode dar. 0 dinheiro que se guarda na poupança para um sonho futuro, esse dinheiro é que tem importância, porque o que é dado por não fazer falta não tem valor para o fiel e muito menos para D eus. ( M ACED O, Isto É Senhor, 22/11/1989).

E tem a garantia dos pastores de que D eus cumprirá sua parte: Ele ficará na obrigação de cumprir Sua Palavra. (M ACEDO, M ensagens, p. 23). E ainda, 0 ditado popular de que 'promessa é dívida' se aplica também a Deus. (CRI VELLA, 501 Pensamentos do Bispo Macedo, p. 103)

A ênfase na necessidade de dízimos e ofertas é explicada pelos líderes da IU RD: caso o fiel não alcance o sucesso almejado, a responsabilidade e a faIha são suas:

É certo que muitas pessoas neste mundo são ricas, mesmo sem possuírem D eus no coração. Vencem, entretanto, porque confiam na força do seu trabal ho, e por isso, são possuidoras de uma riqueza honesta e digna. (...) Reafirmo que nossa vida depende de nós mesmos. (M ACEDO, M ensagens, pp. 27, 22).

Algumas das características do discurso iurdiano denotam a recomendação de autoconfiança; o fiel deve crer nele mesmo, em sua capacidade individual. A estratégia oferecida pela IURD, baseada na Teologia da Prosperidade,esti mula o membro da igreja a ser participativo nos cultos em relação a ofertas e dízimos e reivindicar perante $D$ eus aquilo que lhe pertence por direito. Se to do o discurso sobre espiritualidade vem atrelado à inter venção do Diabo, quando se trata de dinheiro, o fiel tem de ir à luta e buscar a Deus com revolta, que neste caso, assume um sentido de inconformidade com a própria situação: doença, pouco dinheiro, ser empregado assalariado ${ }^{36}$, etc., e é D eus quem tem que assumir Sua posição diante do fiel: a IURD assim o exige. Porque Deus é obrigado - como em um contrato - a fazer sua parte; Ele é pago para isto!

Depende apenas de você o que será feito de sua vida, pois quem decide nosso destino somos nós mesmos. N ão são as outras pessoas; não é Deus, nem o Diabo. (...) Não adianta ficar só jejuando ou orando. É preciso buscar o que você quer; fazer a sua parte,e então falar ousadamente com Deus, revoltado com a si- 
tuação. Você deve dar o primeiro passo, pois Deus não o fará por você.( M ACEDO, M ensagens, p. 28)

As doações em dinheiro ou bens são presentes colocados no altar deD eus, logo, para uma grande bênção, um valioso presente! A fé é um instrumento de troca; uma mercadoria, e nesta relação "toma lá, dá cá", a imagem de D eus torna-se mais próxima e trivializada, em oposição à doutrina difundida pelo protestantismo histórico e pelo catolicismo tradicional, a partir da qual reverência e submissão são enfatizadas.

Dependendo do grau de interesse do ofertante,o presente, por mais caro que se ja, ainda assim se torna barato diante daquilo que está proporcionando ao presenteado. Quando há um profundo laço de afeto, ternura e amor entre o que presenteia e o que recebe, o presente nunca deve ser inferior ao melhor que a pessoa tem condições de dar. (M ACED O, O Perfeito Sacrifício: o significado espiritual do dízimo e ofertas, p. 12)

O fiel deve sacrificar o "seu tudo". A IURD tem uma campanha em que estimula o fiel a doar o máximo que puder na espera da bênção. Muitas pessoas dão tudo o que têm naquele momento de sua vida: uma caderneta de poupança, o dinheiro para comprar comida, o dinheiro para o ônibus, eassim por diante.

Aqueles que vêem as doações das ofertas com maus olhos, ou seja, do ponto de vista meramentemercadológico, principalmente do lado da I greja, também têm dificuldades para compreender a razão da vinda do Filho de Deus ao mundo. (...) haja vista que a oferta está intimamente relacionada com a salvação eterna em Cristo Jesus. (M ACEDO, o Perfeito Sacrifício: o significado espiritual do dízimo e ofertas, p. 14)

0 adepto é conclamado a concorrer por melhores condições num mundo de extrema desigualdade social. $E$ ainda tem de assumir uma responsabilidade a mais: a de ter sucesso, senão sua vida pode estar comprometida com as forças malignas ou com sua própria incapacidade de gerenciar suas possibilidades. Há muitas oportunidades para aqueles que vivem nos bolsões de pobreza? É onde se encontram muitas igrejas da Universal. M as, mesmo assim,é preciso "sacrificar"diante de Deus e, de preferência, em dinheiro: Aque les que examinam o custo do sacrifício jamais sacrificarão uma grande oferta, e aquel es que não sacrificam para a obra de Deus jamais conquistarão qualquer vitória. (CRIVELLA, 501 Pensamentos do Bispo Macedo, p. 21). 
Colocado nestes termos, é o fiel quem decide: Tudo depende de você. Se perseverar, automaticamente conquistará as bênçãos de D eus. E assim, entrará na terra prometida. ( M ACED 0, M ensagens, p. 21).

E a igreja administra a sua doação: A árvore proibida, no paraíso, representava o dízimo, isto é, a parte de D eus na qual o homem não podia sequer tocar, embora pudesse regá-la e fazêla crescer. (CRIVELLA, 501 Pensamentos do Bispo M acedo, pp. 99-100). Já ao fiel cabe expulsar Satanás, participar das correntes de prosperidade,l er sobre como muitosirmãos conseguiram resultados exigindo de Deus o que têm direito. De resto, aquele que não alcançar uma bênção, não dará testemunho nem será citado nos livros.

\section{CONCLUSÃO}

Procuramos, ao longo deste artigo, evidenciar como o movimento pentecostal exerceu, desde suas origens, forte atração sobre as camadas pobres, inaugurando uma prática religiosa singular, diferenciando-se da ética tradicional tanto do catolicismo como do protestantismo histórico. Neste movimento, os poderes sagrados se encontram distribuídos de forma horizontalizada,levando à rotinização do carisma; a soberania de D eusé compartilhada pelos fiéis; o Diabo se vê cotidianamente confrontado pel os membros da comunidade; e, o ideal de pobreza e humildade,i m presso nos Evangelhos, érejeitado em favor de uma nova ética, em que a felicidadee o bem estar são esperados já nesta vida, baseada na Teologia da Prosperidade. Segundo esta doutrina, aqueles que não logram sucesso em seus empreendimentos devem procurar respostas de caráter individual, e não social ou político. Afinal, somente o trabalho, a "posse" dos bens e a solidariedade entre os seus pode garantir uma sociedade igualitária.

Esta posição, ainda que seguramente elitista, prefigura a cosmovisão política dosneopentecostai s,independentementedesua classesocial. Isso porque, a despeito do voto corporativo, da criação de alguns partidos confessionais e do estridente discurso anti-comunista, os neopentecostais latino-americanos, à diferença da M aioria M oral nos Estados Unidos, não possuem uma visão positiva com respeito ao papel do Estado, nem sequer sobrea política. N em mesmo a filantropia é estimulada, pois os excluídos devem recorrer diretamente ao sobrenatural.

Nada devem a estas instituições que, de resto, freqüentemente são vistas como submersas nas forças do maligno. Assim, embora desejem ver um evangélico como presidente da República, tal aspiração deriva do universo religio- 
so, e não de uma intenção de caráter pragmático, para atender ao desígnio Fe liz éa nação cujo Deus éo Senhor (Salmo 33: 12).

Daí o menosprezo e desinteresse para com as ideologias seculares, porquanto o seu governo não é deste mundo. Ademais, sua experiência concreta não é, no geral, de quem vê seus direitos garantidos, mas a de permanentes devedores.

Em virtude de tais configurações, e uma vez que o voto é obrigatório, as lideranças neopentecostai s freqüentemente se dispõem a negociar seu apoio junto às mais diversas agremiações, sejam de esquerda ou de direita, para 0 que apresentam suas reivindicações imediatas em troca da adesão dos fiéis. $E$ é justamente aí que reside seu percentual de poder: apresentar-se como uma reserva moral a ser conquistada pelos que disputam a liderança política no flexível e instável mercado da opinião pública.

\section{NOTAS}

'PADILLA, René. “Los evangélicos: Nuevos actores en el escenario politico latinoamericano". In Dela marginacion al compromiso. Quito: FTL, 1991, p. 5.

${ }^{2}$ Denomina-se evangélico, na América Latina, a todos os membros das confissões religiosas cristãs a-católicas e cuja origem sejam as missões de evangelização.

${ }^{3}$ M ARIAN O, Ricardo. "Os pentecostais e a teologia da prosperidade". In N ovos Estudos. São Paulo: CEBRAP, 1996, no 44, p. 24 e ss.

${ }^{4}$ M ARTIN, David. Tongs of Fire. Basis Blackwell: Cambridge, 1989, p.51.

${ }^{5}$ Sinal do Espírito Santo sobre os apóstolos no dia de Pentecostes, conforme o Livro A tos dos Apóstolos.

${ }^{6}$ M ONTEROSSA, M ardoqueo Carranza. "El salvador: ingreso a un mundo desconocido". In Dela marginacion al compromiso. Quito: FTL, 1991, p. 54.

${ }^{7}$ M ARTIN, David. Op.cit., p. 86.

${ }^{8}$ Denomina-se protestante ou protestanti smo histórico as denominações que procedem das igrejas Reformadas, instaladas na América Latina, em sua grande maioria por imigrantes europeus.

${ }^{9}$ FRESTON, Paul. "Pentecostalism in Latin America”. In Social Compass. Louvain: Groupe de Sciences Sociales des Religions, vol.45, no 3, 1998, p. 337.

${ }^{10}$ STO LL,D avid. Is Latin America turning protestant? Los Angeles: University of California Press, 1990, pp. 8-9.

${ }^{11}$ VEJA, 16 de maio de 1990, p. 47.

${ }^{12}$ KEPEL, Gilles. A revanche de Deus. São Paulo: Siciliano, 1991, p. 138 ess. 
${ }^{13}$ GALIN D O, Florencio. 0 fenômeno das seitas fundamentalistas. Petrópolis: Vozes,1995, pp.190-91.

${ }^{14} \mathrm{~A}$ propósito desta questão, considerem-se as diferenças estabelecidas por Weber entre 0 carisma em função das qualidad es intrínsecas do sacerdote e o cari sma em função do cargo (WEBER, Economía y sociedad. M exico, Fondo de Cultura Económica, 1997, p. 199).

${ }^{15}$ CAM POS, Leonildo. Teatro, templo e mercado; organização emarketing de um empreendimento pentecostal. Petrópolis/São Paulo, Vozes/U M ESP, 1999, p. 409 ess.

${ }^{16}$ GALINDO, F. Op. cit, p. 185 e ss.KEPEL,M ARIAN O. Op. cit, pp. 24-46.;FRY, Peter. “Duas respostas para a aflição: umbanda e pentecostalismo". In D ebate eCrítica no4,s/d, p. 43 e SS.

${ }^{17}$ Sobre a atenção e estigmatização que os meios de comunicação de massa dispensam ao pentecostalismo, cite-se o exemplo do Brasil, principalmenteda Rede Globo, maior cadeia televisa do País, que ataca frontalmente a I greja Universal do Reino de Deus, proprietária da Rede Record,esta, detentora de um razoável índice de audiência. A este respeito, ver: ALM EIDA, Ronaldo. "A universalização do Reino de D eus". In Novos Estudos. São Paulo: CEBRAP, 1996, $\mathrm{n}$-44, p. 12 ess.

${ }^{18}$ M ENSCHING, G. Die Religion. Stuttgart, 1959, S. 18.

${ }^{19}$ Consider amos determinadas exceções merecedoras de destaque, como éo caso da I greja do Evangelho Quadrangular ou as organizações paraeclesiásticas de ajuda mútua.

${ }^{20}$ PADILLA,R. O p. cit, p. 10. A esterespeito, ver ainda: PADILLA, René. El evangelio hoy. Buenos Aires: Certeza, 1975.

${ }^{21}$ M ARTIN, D. op. cit, p. 19 ess.

${ }^{22}$ TH OM PSO N ,E.P. A formação da classe operária inglesa. Rio de Janeiro: Paz eTerra,1987 (vol. 2).

${ }^{23}$ FRESTON, Paul. O p. cit., p.348 (tradução livre das autoras).

${ }^{24}$ Sobre a importância do Espírito Santo nesta constelação sagrada, ver: BAPTIST A, Selma. A historicidade da fé, o discurso profético e a prática pentecostal: elementos para a análise de uma dimensão fugidia. História: questões e debates. Curitiba: Editora da U FPR, n. 28, pp. 11-40, 1998.

${ }^{25}$ FRESTON . O p. cit., p. 349.

${ }^{26}$ BREPOHL DE M AGALHÃES, M arion. Pangermanismo e nazismo; a trajetória alemã rumo ao Brasil. Campinas: Editora da U N ICAM P/ FAPESP, 1998.

${ }^{27}$ FRESTON. O p. cit., p. 353.

${ }^{28}$ KEPEL. Op. cit., 1996, p. 147.

${ }^{29}$ STOLL. Op. cit, p. 67.

${ }^{30}$ Para os adeptos da Teologia da Prosperidade, os homens são alvo da disputa entre Deus e o Diabo, em franca batalha espiritual, sendo a prosperidade para seus filhos o desejo inconteste do primeiro, e o sofrimento e as privações, do segundo. Ainda que não tenhamos bases sólidas para realizar tal comparação, ao que nos parece, estas convicções se asseme- 
Iham às dos primeiros puritanos ingleses, no século XVII.A este respeito, ver: DORN VAN ROSSU M , Gerhard. "Die puritanische Familie”. In REIF, H einz. Die Familie in der Geschichte. Göttingen: Vandenhoeck \& Ruprecht, 1982, pp. 61-81.

${ }^{31}$ Além da I greja Universal do Reino de Deus,fundada em 1977, e quejá possui seguidores em diversos países da América latina e da Europa, no Brasil a Teologia da Prosperidade é absorvida também pelas Igrejas Renascer em Cristo, Comunidade Evangélica Sara N ossa Terra, Nova Vida,Bíblica da Paz, Cristo Salva, Cristo Vive, Verbo da Vida, Nacional do Senhor Jesus Cristo e pelas organizações Adhonep, Mi ssão Shekinah e Internacional da Graça de $D$ eus, todas elas com representantes em outros países da América Latina e da península Ibérica.

${ }^{32}$ GOM ES, Wilson. "Nem anjos nem demônios". In Nem anjos nem demônios: interpretações soci ológicas do pentecostalismo. Petrópolis: Vozes, 1994, p. 229 e ss.

${ }^{33}$ SOUZA, Etiane Caloy B. "A demonização do cotidiano pela I greja Universal do Reino de Deus". In História Questões \& Debates. Curitiba: Ed. UFPR, 2001, no. 33, p. 135 ess.

${ }^{34} \mathrm{KEPEL}$, Gilles. A revanche de Deus: cristãos, judeus e muçulmanos na reconquista do mundo. São Paulo: Siciliano, 1991, p. 134.

${ }^{35}$ N O GUEIRA, Carlos Roberto F. O Diabo no Imaginário Cristão. São Paulo: Ática, 1986.

${ }_{36}$ "Ser empregado" tem sido gradativamente desqualificado por Edir M acedo, poiso assalariado não é um indivíduo autônomo ou independente. Por isso, há uma recomendação no sentido de estimular o fiel a ter seu próprio negócio, ainda que pequeno, favorecendo, por exemplo, a participação do trabalhador na economia informal. Um outro aspecto relevante é o incentivo para que os irmãos apóiem uns aos outros, procurando os serviços de que necessitem entre os membros da I greja. Essas duas práticas têm favorecido, pelo menos a curto prazo, a melhoria das condições de vida dos fiéis da IURD.

Artigo recebido em 01/2002. Aprovado em 05/2002. 